\title{
24. ISOTOPIC COMPOSITION OF INTERSTITIAL FLUIDS AND ORIGIN OF METHANE IN SLOPE SEDIMENT OF THE MIDDLE AMERICA TRENCH, DEEP SEA DRILLING PROJECT LEG 84
}

\author{
George E. Claypool and Charles N. Threlkeld, U.S. Geological Survey, Denver \\ Paul N. Mankiewicz, Global Geochemistry Corporation, Canoga Park \\ Michael A. Arthur, University of Rhode Island \\ and \\ Thomas F. Anderson, University of Illinois ${ }^{2}$
}

\begin{abstract}
$\mathrm{CH}_{4}$ and $\mathrm{CO}_{2}$ species in pore fluids from slope sediments off Guatemala show extreme ${ }^{13} \mathrm{C}$-enrichment $\left(\delta^{13} \mathrm{C}\right.$ of -41 and $+38 \%$, respectively) compared with the typical degree of ${ }^{13} \mathrm{C}$-enrichment in pore fluids of DSDP sediments $\left(\delta^{13} \mathrm{C}\right.$ of -60 and $\left.+10 \%\right)$. These unusual isotopic compositions are believed to result from microbial decomposition of organic matter, and possibly from additional isotopic fractionation associated with the formation of gas hydrates. In addition to the isotopic fractionation displayed by $\mathrm{CH}_{4}$ and $\mathrm{CO}_{2}$, the pore water exhibits a systematic increase in $\delta^{18} \mathrm{O}$ with decrease in chlorinity. As against seawater $\delta^{18} \mathrm{O}$ values of 0 and chlorinity of $19 \%$, the water collected from decomposed gas hydrate from Hole 570 had a $\delta^{18} \mathrm{O}$ of $+3.0 \%$ and chlorinity of $9.5 \%$. The isotopic compositions of pore-fluid constituents change gradually with depth in Hole 568 and discontinuously with depth in Hole 570.
\end{abstract}

\section{INTRODUCTION}

Previous drilling on DSDP Legs 66 and 67 demonstrated the presence of gas-charged sediments and gas hydrates on the continental slope of Middle America. The sampling and analytical programs on these earlier legs, however, were not specifically designed for the study of gassy sediments. In addition, the presence of gas hydrate and the possibility of free gas beneath the gas hydrate zone prevented achievement of some of the drilling objectives. Subsequently, Leg 84 was scheduled to drill in the same area as Leg 67. Drilling objectives for Leg 84 were selected in areas where gas hydrates were believed not to be a problem, or where they could be reached at depths shallower than the base of the gas hydrate zone. In addition, one site was selected for the specific study of gas hydrates, with specialized equipment to be deployed. This is the second site selected for intensive study of gas hydrates, the first being Site 533 on Leg 76 (Kvenvolden and Barnard, 1983).

On Leg 84 , Site 568 was selected for intensive study of gas hydrates. Interstitial fluid samples were collected at closely spaced depth intervals. The pressure core barrel was used in an attempt to sample gas hydrates. Readily observable gas hydrate was recovered in Hole 568, and an unexpected layer of relatively pure gas hydrate, 3 to $4 \mathrm{~m}$ thick, was cored in Hole 570 , with about $1 \mathrm{~m}$ of gas hydrate recovered. Minor gas hydrate occurrences were also observed in Holes 565, and possibly in Holes 566 and 569 (Kvenvolden and McDonald, this volume).

\footnotetext{
${ }^{1}$ von Huene, R., Aubouin, J., et al., Init. Repts. DSDP, 84: Washington (U.S. Govt. Printing Office).

Addresses: (Claypool and Threlkeld) U.S. Geological Survey, MS 977, Box 25046, Denver, CO 80225; (Mankiewicz) Global Geochemistry Corp., Canoga Park, CA; (Arthur) Univ. of Rhode Island, Kingston, RI; (Anderson) Univ. of Illinois, Champaign-Urbana, IL.
}

In this chapter, we present the results of chemical and isotopic analyses of the interstitial fluids (gas and water) from selected Holes on Leg 84. Also, we discuss the diagenetic processes responsible for the gas and possible effects of gas hydrate stability and occurrence on the operation of these diagenetic processes.

\section{SAMPLES AND METHODS}

Sediment gas and interstitial water were sampled according to standard DSDP procedures (Gealy and Dubois, 1971; Manheim, 1966). Gases were analyzed by the procedures of Claypool et al. (1980) and Schoell (1980), with modifications. Water samples were analyzed by the techniques of Presley and Claypool (1971) and Epstein and Mayeda $(1953) .{ }^{13} \mathrm{C} /{ }^{12} \mathrm{C},{ }^{18} \mathrm{O} /{ }^{16} \mathrm{O}$, and $\mathrm{D} / \mathrm{H}$ were measured by standard techniques on $\mathrm{CO}_{2}$ and $\mathrm{H}_{2}$ gas; the results are expressed in the delta notation $\left(\delta, \% 0=\left\{\left[R_{\text {sample }} / R_{\text {standard }}\right]-1\right\} 10^{3}\right.$, where $R={ }^{13} \mathrm{C} /{ }^{12} \mathrm{C}$, ${ }^{18} \mathrm{O} /{ }^{16} \mathrm{O}, \mathrm{D} / \mathrm{H}$ ) relative to the standards PeeDee belemnite (PDB) for carbon and standard mean ocean water (SMOW) for hydrogen and oxygen.

\section{RESULTS}

Pore-water samples from three holes $(565,568,570)$ are listed by depth of burial in Table 1 . The concentration and $\delta^{13} \mathrm{C}$ of total dissolved carbonate $\left(\mathrm{\Sigma CO}_{2}\right)$ and the $\delta^{18} \mathrm{O}$ of the water are reported, along with the shipboard determinations of chlorinity and titration alkalinity.

The chemical and isotopic compositions of gas samples from Holes 565, 568, and 570 are given by depth of burial in Table 2. The $\delta^{13} \mathrm{C}$ of $\mathrm{CH}_{4}$ is given for each sample. On about half of the samples, $\delta \mathrm{D}$ of the $\mathrm{CH}_{4}$ was measured, and for fewer samples, $\delta^{13} \mathrm{C}$ of the $\mathrm{CO}_{2}$ was also measured.

Selected data from Tables 1 and 2 are plotted in Figure 1. The carbon isotopic compositions of $\mathrm{CH}_{4}$ and total dissolved $\mathrm{CO}_{2}\left(\mathrm{\Sigma CO}_{2}\right)$ in the interstitial water show similar trends at each of the three sites, but with signifi- 
Table 1. Concentration and $\delta^{13} \mathrm{C}$ of total dissolved carbonate, and $\delta^{18} \mathrm{O}$ of interstitial waters, with chlorinity and alkalinity, Sites 565,568 , and 670 , DSDP Leg 84.

\begin{tabular}{|c|c|c|c|c|c|c|}
\hline \multirow[b]{2}{*}{ Hole-Core-Section } & \multirow{2}{*}{$\begin{array}{l}\text { Sub-bottom } \\
\text { depth } \\
\text { (m) }\end{array}$} & \multicolumn{2}{|c|}{$\mathrm{\Sigma CO}_{2}$} & \multirow[b]{2}{*}{$\begin{array}{l}\delta^{18} \mathrm{O} \\
(\% 0)\end{array}$} & \multirow[b]{2}{*}{$\begin{array}{c}\text { Chlorinity } \\
\left(\%_{0}\right)\end{array}$} & \multirow{2}{*}{$\begin{array}{l}\text { Titration } \\
\text { alkalinity } \\
\left(\text { meq L }{ }^{-1}\right)\end{array}$} \\
\hline & & $\left(\mathrm{mmol} \mathrm{kg}^{-1}\right)$ & $\begin{array}{l}\delta^{13} \mathrm{C} \\
(\% 0)\end{array}$ & & & \\
\hline $565-1-5$ & 7.4 & 3.1 & -11.8 & $-^{b}$ & 19.1 & 4.7 \\
\hline $565-2-5$ & 17.9 & 7.4 & -25.8 & +0.47 & 19.0 & 11.2 \\
\hline $565-3-5$ & 27.4 & 11.6 & -28.1 & - & 18.6 & 19.5 \\
\hline $565-5-5$ & 46.4 & - & +7.5 & - & 17.3 & 29.9 \\
\hline $565-6-4$ & 54.4 & 19.8 & +9.5 & +0.47 & 17.0 & 28.5 \\
\hline $565-8-4$ & 73.4 & 27.6 & +13.6 & +0.51 & 16.5 & 38.4 \\
\hline $565-11-1$ & 97.4 & 25.9 & +14.4 & - & 15.2 & 34.7 \\
\hline $565-13-5$ & 122.4 & 19.8 & +15.1 & - & 14.4 & 37.2 \\
\hline $565-17-1$ & 154.4 & 20.0 & +16.6 & -0.16 & 14.2 & 27.8 \\
\hline $565-19-3$ & 176.4 & 16.1 & +16.8 & - & 14.0 & 23.4 \\
\hline $565-23-1$ & 211.4 & 11.0 & +15.7 & - & 13.8 & 15.1 \\
\hline $565-27-5$ & 255.4 & 6.3 & +13.9 & - & 15.3 & 9.3 \\
\hline $565-29-6$ & 275.9 & 7.2 & - & - & 13.9 & 10.3 \\
\hline $568-1-1$ & 1.4 & 11.2 & -14.8 & +2.85 & - & - \\
\hline $568-1-2$ & 3.0 & 27.5 & -13.5 & +0.28 & 19.1 & 41.5 \\
\hline $568-2-3$ & 7.9 & 26.9 & -16.4 & +0.34 & - & - \\
\hline $568-3-4$ & 19.0 & 69.0 & +12.7 & +0.37 & 18.6 & 85.3 \\
\hline $568-4-3$ & 27.2 & 75.0 & +15.1 & +0.37 & 18.2 & 88.2 \\
\hline $568-5-4$ & 38.3 & 88.5 & +16.2 & +0.61 & 18.1 & 97.1 \\
\hline $568-6-4$ & 48.0 & 99.7 & +17.4 & +1.05 & 17.1 & 118.5 \\
\hline $568-8-5$ & 68.1 & 90.9 & +18.3 & - & 16.1 & 115.8 \\
\hline $568-10-3$ & 84.6 & 70.5 & +18.9 & +0.71 & 16.0 & 93.4 \\
\hline $568-12-3$ & 103.3 & 64.3 & +19.8 & - & 14.5 & 84.5 \\
\hline $568-14-4$ & 123.8 & 47.2 & +20.3 & +1.18 & 13.6 & 64.9 \\
\hline $568-18-4$ & 162.5 & 19.1 & +23.4 & +1.64 & 12.5 & 25.7 \\
\hline $568-24-4$ & 220.7 & 7.3 & +25.9 & - & 13.3 & 11.5 \\
\hline $568-32-5$ & 299.4 & 6.3 & +23.1 & +2.20 & 12.0 & 9.8 \\
\hline $568-36-4$ & 336.9 & 7.4 & +26.9 & +2.48 & 11.4 & 10.6 \\
\hline $568-43-2$ & 401.7 & 14.8 & +35.7 & +3.02 & 9.5 & 20.5 \\
\hline $570-1-3$ & 4.5 & 26.1 & -24.5 & +0.26 & 19.5 & 36.8 \\
\hline $570-4-3$ & 31.7 & 38.7 & +7.7 & - & 19.5 & 51.0 \\
\hline $570-6-5$ & 53.9 & 36.4 & +9.9 & +0.51 & 19.0 & 52.9 \\
\hline $570-10-1$ & 86.6 & 51.3 & +10.2 & - & 19.0 & 63.1 \\
\hline $570-16-5$ & 150.5 & 39.7 & +14.0 & +0.08 & 18.2 & 51.9 \\
\hline $570-20-1$ & 183.3 & 27.8 & +15.3 & +0.13 & 18.8 & 41.3 \\
\hline $570-27$ (hydrate) & 249.0 & - & - & +3.72 & 0.7 & - \\
\hline $570-25-3$ & 234.2 & 16.6 & +21.2 & - & 18.5 & 27.4 \\
\hline $570-30-3$ & 279.5 & 13.0 & +37.5 & - & 14.3 & 18.1 \\
\hline $570-36-1$ & 337.1 & 2.2 & +27.1 & +1.74 & 8.9 & 3.7 \\
\hline
\end{tabular}

cantly more ${ }^{13} \mathrm{C}$-enrichment at greater depths in Holes 568 and 570, compared with Hole 565.

The $\Sigma \mathrm{CO}_{2}$ and titration alkalinity profiles with depth are also quite different at the three drill sites. In Hole $565, \Sigma \mathrm{CO}_{2}$ and alkalinity maxima of about $30 \mathrm{mmol} / \mathrm{kg}$ and $40 \mathrm{meq} / \mathrm{L}$, respectively, are observed at depths of about 70 to $100 \mathrm{~m}$, and decrease regularly with increasing depth, approaching seawater values at depths below about $256 \mathrm{~m}$. In Hole 458 , maxima of $100 \mathrm{mmol} / \mathrm{kg}$ and $118 \mathrm{meq} / \mathrm{L}$ occur at about $50 \mathrm{~m}$ depth, and decrease to about $7 \mathrm{mmol} / \mathrm{kg}$ and $10 \mathrm{meq} / \mathrm{L}$ below $200 \mathrm{~m}$. In Hole $570, \Sigma \mathrm{CO}_{2}$ and titration alkalinity increase to $51 \mathrm{mmol} / \mathrm{kg}$ and $63 \mathrm{meq} / \mathrm{L}$ at about $90 \mathrm{~m}$, then decrease regularly to seawater values below $300 \mathrm{~m}$.

Where the $\delta^{13} \mathrm{C}$ of $\mathrm{CO}_{2}$ in gas samples has been measured, the estimated difference between the coexisting $\mathrm{CO}_{2}$ gas and $\Sigma \mathrm{CO}_{2}$ is about 11 to $14 \%$, the $\mathrm{CO}_{2}$ gas being lighter in all cases.

The $\delta \mathrm{D}-\delta^{13} \mathrm{C}$ crossplot (Fig. 2) for $\mathrm{CH}_{4}$ shows different trends in Holes 568 and 570 . Significantly more D-enrichment in $\mathrm{CH}_{4}$ occurs at depth in Hole 568 .
The $\delta^{18} \mathrm{O}$ of the pore water is plotted against chlorinity in Figure 3. The same general trend of increasing $\delta^{18} \mathrm{O}$ with decreasing chlorinity is observed in the Leg 84 data as was previously observed in this same area on Leg 67 (Harrison et al., 1982).

\section{DISCUSSION}

Hole 565 was drilled in $3111 \mathrm{~m}$ of water on the landward slope of the Middle America Trench off Costa Rica. Gas hydrate was recovered from a sandstone at a depth of about $278 \mathrm{~m}$ in Core 565-30. Isotopic composition of the major pore-fluid constituents in Hole 565 is fairly typical of other DSDP sites. Holes 568 and 570 were drilled in 2300 and $1700 \mathrm{~m}$ of water, respectively, off Guatemala. In comparison with Hole 565, the porefluid chemistry of Holes 568 and 570 is unusual and is the focus of the following discussion.

The interstitial-fluid chemistry of DSDP Leg 84 sediments is unique in at least three respects. First, extremely ${ }^{13} \mathrm{C}$-enriched $\mathrm{\Sigma CO}_{2}$ occurs in Holes 568 and 570 . Second, samples of gas hydrate were recovered in both Hole 
Table 2. Isotopic composition of $\mathrm{CH}_{4}$ and $\mathrm{CO}_{2}$ in gas samples from void-spaces in cores, Sites 565, 568, and 570, DSDP Leg 84 .

\begin{tabular}{|c|c|c|c|c|}
\hline \multirow[b]{2}{*}{ Hole-Core-Section } & \multirow{2}{*}{$\begin{array}{l}\text { Sub-bottom } \\
\text { depth } \\
\text { (m) }\end{array}$} & \multicolumn{2}{|c|}{$\mathrm{CH}_{4}$} & \multirow{2}{*}{$\begin{array}{c}\mathrm{CO}_{2} \\
\delta^{13} \mathrm{C}_{\mathrm{PDB}}{ }_{\left(\%_{0}\right)}\end{array}$} \\
\hline & & $\begin{array}{c}\delta^{13} \mathrm{C}_{\mathrm{PDB}} \\
\left(\%_{0}\right)\end{array}$ & $\underset{\left(\%_{0}\right)}{\delta D_{\text {SMOW }}}$ & \\
\hline $565-6-6$ & 58 & -73.3 & $-{ }^{a}$ & - \\
\hline $565-19-4$ & 177 & -66.3 & - & - \\
\hline $565-24-3$ & 223 & -64.7 & - & - \\
\hline $565-29-2$ & 270 & -61.8 & - & - \\
\hline $565-33, \mathrm{CC}$ & 319 & -62.2 & - & - \\
\hline $565-34-1$ & 320 & -63.6 & - & - \\
\hline $568-4.4$ & 28 & -70.8 & -196 & - \\
\hline $568-5-5$ & 39 & -68.0 & - & - \\
\hline $568-6-4$ & 47 & -67.3 & -194 & +3.4 \\
\hline $568-7-3$ & 56 & -66.3 & - & - \\
\hline $568-8-5$ & 68 & -65.8 & -192 & +6.3 \\
\hline $568-9-4$ & 76 & -65.6 & - & - \\
\hline $568-10-4$ & 85 & -65.3 & -196 & +5.6 \\
\hline $568-12-4$ & 104 & -63.9 & - & - \\
\hline $568-13-4$ & 114 & -63.4 & -194 & +9.8 \\
\hline $568-14-6$ & 126 & -63.0 & - & - \\
\hline $568-15-6$ & 135 & -62.3 & -193 & - \\
\hline $568-16-4$ & 137 & -61.2 & -198 & - \\
\hline $568-17-4$ & 153 & -59.8 & - & - \\
\hline $568-18-3$ & 160 & -57.4 & -191 & - \\
\hline $568-19-7$ & 176 & $(-39.8)^{b}$ & $(-120)$ & - \\
\hline $568-20-6$ & 184 & -54.6 & - & - \\
\hline $568-22-5$ & 202 & -51.5 & -180 & - \\
\hline $568-23-2$ & 207 & -50.1 & -177 & - \\
\hline $568-24-4$ & 220 & -49.5 & - & - \\
\hline $568-25-6$ & 232 & -48.8 & -171 & - \\
\hline $568-27-3$ & 247 & -47.6 & - & - \\
\hline $568-28-4$ & 259 & -47.1 & -171 & - \\
\hline $568-29-5$ & 270 & -46.7 & - & - \\
\hline $568-30-6$ & 281 & -46.4 & -166 & - \\
\hline $568-32-6$ & 300 & -46.5 & - & - \\
\hline $568-33-6$ & 310 & -46.3 & -164 & +0.2 \\
\hline $568-35-4$ & 327 & -46.0 & - & - \\
\hline $568-34-6$ & 320 & -45.9 & -162 & - \\
\hline $568-36-6$ & 339 & -45.4 & -161 & - \\
\hline $568-37-4$ & 346 & -44.3 & - & - \\
\hline $568-38-6$ & 359 & -45.0 & -164 & - \\
\hline $568-39-3$ & 363 & -45.5 & - & - \\
\hline $568-40-3$ & 373 & -44.2 & -161 & - \\
\hline $568-41-5$ & 386 & -44.3 & - & - \\
\hline $568-42-6$ & 398 & -41.2 & -145 & - \\
\hline $568.43-4$ & 404 & $-42.9,-44.3$ & - & - \\
\hline $568-44-4$ & 414 & -43.2 & - & - \\
\hline $570-2-5$ & 11.4 & -83.4 & -208 & - \\
\hline $570-4-2$ & 30 & -77.4 & - & - \\
\hline $570-6-5$ & 53 & -73.8 & - & - \\
\hline $570-7-4$ & 61 & -71.6 & -193 & -2.0 \\
\hline $570-8-3$ & 69 & -70.5 & -191 & +0.3 \\
\hline $570-9-2$ & 78 & -69.4 & - & - \\
\hline $570-10-2$ & 88 & -70.3 & -193 & -0.4 \\
\hline $570-11-1$ & 96 & -69.2 & - & - \\
\hline $570-14-5$ & 130 & -68.6 & -193 & -0.2 \\
\hline $570-15-2$ & 136 & -68.9 & - & - \\
\hline $570-16-6$ & 151 & -68.2 & -191 & +0.3 \\
\hline $570-17-3$ & 157 & -67.5 & - & - \\
\hline $570-18-1$ & 164 & -67.3 & -190 & -0.2 \\
\hline $570-19-3$ & 176 & -66.1 & - & - \\
\hline $570-20-1$ & 183 & -65.1 & -191 & +1.2 \\
\hline $570-21-2$ & 193 & -63.1 & - & - \\
\hline $570-22-3$ & 205 & -62.0 & -191 & +4.0 \\
\hline $570-23-2$ & 213 & -60.3 & - & - \\
\hline $570-24-3$ & 224 & -58.0 & -185 & - \\
\hline $570-25-4$ & 234 & -56.4 & - & - \\
\hline $570-26-4$ & 245 & -54.4 & -189 & - \\
\hline $570-27-1$ & 250 & -43.6 & -178 & - \\
\hline $570-27-1$ & 250 & -40.3 & -163 & - \\
\hline $570-28$ & 265 & -39.6 & -183 & - \\
\hline $570-28-6$ & 267 & -43.4 & - & - \\
\hline $570-29$ & 270 & -38.7 & -188 & - \\
\hline $570-29-4$ & 274 & -43.0 & -185 & +15.6 \\
\hline $570-30-4$ & 284 & -42.9 & -188 & +15.2 \\
\hline $570-31-1$ & 289 & -42.8 & - & - \\
\hline $570-32-4$ & 302 & -42.7 & -196 & - \\
\hline $570-34-1$ & 318 & -42.2 & -187 & - \\
\hline $570-35-2$ & 329 & -42.0 & -188 & - \\
\hline $570-36-1$ & 336 & -41.7 & -185 & - \\
\hline $570-37-1$ & 347 & -41.0 & - & - \\
\hline $570-41-2$ & 386 & -41.9 & - & - \\
\hline
\end{tabular}

a $-=$ no analysis

$\mathrm{b}$ Values in parentheses are suspect because of deviation from trends.
568 and Hole 570 at about the depths at which the greatest ${ }^{13} \mathrm{C}$-enrichment in $\mathrm{CH}_{4}$ and $\mathrm{CO}_{2}$ occurs. And third, low-chlorinity and ${ }^{18} \mathrm{O}$-enriched pore water was present in Holes 568 and 570, confirming earlier observations from Leg 67 (Harrison et al., 1982). These unusual aspects of pore-fluid chemistry are undoubtedly related to the presence of gas hydrate, but the nature of the relationship is unclear. We know from observations on samples from Hole 533 (Claypool and Threlkeld, 1983) and Hole 565 (this chapter) that gas hydrate occurrence is not always accompanied by such degrees of ${ }^{13} \mathrm{C}$-enrichment in $\mathrm{CH}_{4}$ and $\mathrm{CO}_{2}$. This suggests that the isotope effects are somehow related to the unusually organic-carbon-rich nature of these upper-rise and slope sediments off Guatemala. For example, is the extreme ${ }^{13} \mathrm{C}$-enrichment in $\mathrm{CH}_{4}$ and $\mathrm{\Sigma CO}_{2}$ due to an isotope effect associated with more extensive gas hydrate formation? Or do unusually rapid rates of $\mathrm{CH}_{4}$ generation occur at certain depths, leading to (1) extreme ${ }^{13} \mathrm{C}$-enrichment in dissolved $\mathrm{CH}_{4}$ and $\mathrm{CO}_{2}$ (because of kinetic ${ }^{12} \mathrm{C}$-depletion or diminished fractionation at more rapid rates) and (2) localized high concentrations of $\mathrm{CH}_{4}$ and consequent localized gas hydrate formation?

Abundant $\mathrm{CH}_{4}$ is required for the formation of gas hydrates. This $\mathrm{CH}_{4}$ could be supplied to the sediments in two ways: first, by microbiological degradation of organic matter buried with the sediments; and second, by upward migration of natural gas generated by thermal degradation of organic matter in deeper, hotter sediments. Biogenic and thermogenic $\mathrm{CH}_{4}$ occurrences are usually distinguished on the basis of isotopic and chemical compositions (Fuex, 1977; Schoell, 1983). Biogenic $\mathrm{CH}_{4}$ generally has $\delta^{13} \mathrm{C}$ more negative than -60 to $-55 \%$, and is associated with very low contents $(<0.1 \%)$ of $\mathrm{C}_{2}$ hydrocarbons. Thermogenic $\mathrm{CH}_{4}$ usually has $\delta^{13} \mathrm{C}$ of -45 to $-30 \%$, and is accompanied by $1 \%$ or more of $\mathrm{C}_{2}$ hydrocarbons (except for $\mathrm{CH}_{4}$ originating at very high temperatures). The $\delta^{13} \mathrm{C}$ of $\mathrm{CH}_{4}$ is more negative than $-60 \%$ in sediments at all depths in Hole 565 , and in sediments at depths shallower than about $150 \mathrm{~m}$ in Hole 568 , or shallower than $200 \mathrm{~m}$ in Hole 570 (Fig. 1). However, $\mathrm{CH}_{4}$ with $\delta^{13} \mathrm{C}$ of $-45 \% 0$ or heavier occurs in Hole 568 sediments below $350 \mathrm{~m}$, and in Hole 570 sediments below $250 \mathrm{~m}$. Thus, the $\delta^{13} \mathrm{C}$ evidence alone could be interpreted to indicate the presence of biogenic gas in Hole 565 and the presence of both biogenic and thermogenic gas in Holes 568 and 570. The $\mathrm{C}_{2+}$ contents are very low $(<0.05 \%)$ in all cases, but this does not necessarily eliminate the possibility of a thermogenic origin for the isotopically heavy $\mathrm{CH}_{4}$, because gases can become depleted in $\mathrm{C}_{2+}$ hydrocarbons as a result of extensive migration (Coleman et al., 1977; Schoell, 1983).

The main evidence against significant amounts of upward-migrating thermogenic $\mathrm{CH}_{4}$ in Guatemala slope sediments at shallow depths is the relationship between the $\delta^{13} \mathrm{C}$ of coexisting $\mathrm{CH}_{4}$ and $\mathrm{CO}_{2}$ (Fig. 1). In Holes 568 and 570 , the $\delta^{13} \mathrm{C}_{\text {of }} \mathrm{CH}_{4}$ is $-41 \%$ (which is unusually positive for biogenic gas in marine sediments) near depths where the $\delta^{13} \mathrm{C}$ of coexisting $\Sigma \mathrm{CO}_{2}$ is +36 to $+38 \%$ (a value which makes this residual pore-water 

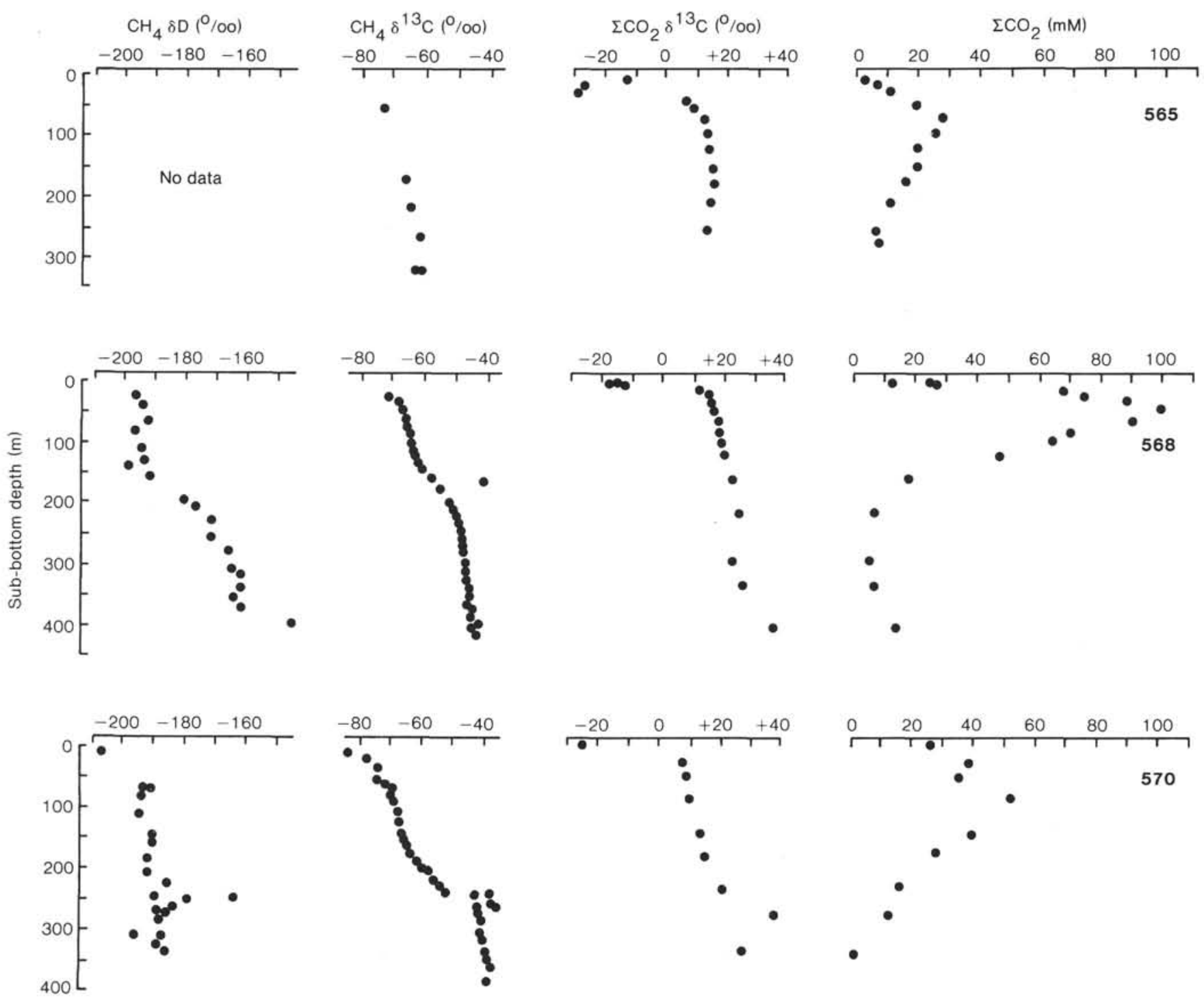

Figure 1. Isotopic composition ( $\delta \mathrm{D}$ and $\delta^{13} \mathrm{C}$ ) of $\mathrm{CH}_{4}$ in gas, and isotopic composition $\left(\delta^{13} \mathrm{C}\right)$ and concentration of total dissolved $\mathrm{CO}_{2}$ in pore-water samples from DSDP Sites 565, 568, and 570.

$\mathrm{CO}_{2}$ among the most ${ }^{13} \mathrm{C}$-enriched naturally occurring substances observed on Earth).

The $77 \% 0 \delta^{13} \mathrm{C}$ difference between $\mathrm{CH}_{4}(-41 \%)$ and $\Sigma \mathrm{CO}_{2}(+36 \%)$ is essentially the same as the $\delta^{13} \mathrm{C}$ difference in DSDP cores from other sites where $\mathrm{CH}_{4}$ with $\delta^{13} \mathrm{C}$ as negative as $-90 \%$ has been observed (e.g., Hole 533, Leg 76; Claypool and Threlkeld, 1983). The observed $\delta^{13} \mathrm{C}$ difference between coexisting $\mathrm{CH}_{4}$ and $\mathrm{\Sigma CO}_{2}$ is interpreted as resulting from a kinetic isotope effect associated with bacterial $\mathrm{CO}_{2}$ reduction (Rosenfeld and Silverman, 1959). $\mathrm{CO}_{2}$ reduction is the main process by which $\mathrm{CH}_{4}$ originates in marine sediments during early diagenesis (Claypool and Kvenvolden, 1983). When $\mathrm{CH}_{4}$ is generated in sediments, the $\Sigma \mathrm{CO}_{2}$ reservoir becomes depleted in ${ }^{12} \mathrm{C}$ because of the preferential removal of ${ }^{12} \mathrm{C}$ enriched $\mathrm{CO}_{2}$ to form $\mathrm{CH}_{4}$. In Figure 1, this is shown by the rapid increase in $\delta^{13} \mathrm{C}$ of $\Sigma \mathrm{CO}_{2}$ from negative to positive values just beneath the shallowest depth of significant $\mathrm{CH}_{4}$ occurrence in the cores from Holes 565, 568, and 570. The $\delta^{13} \mathrm{C}$ of the $\Sigma \mathrm{CO}_{2}$ reservoir undergoing $\mathrm{CH}_{4}$ generation usually levels off at some positive value around +10 to $+15 \%$. A possible explanation for this tendency of the $\Sigma \mathrm{CO}_{2}$ reservoir to reach a constant $\delta^{13} \mathrm{C}$ value during $\mathrm{CH}_{4}$ generation is that additional $\mathrm{CO}_{2}$ with $\delta^{13} \mathrm{C}$ of about $-25 \% 0$ is continually added by fermentation and decarboxylation processes, which establishes an isotopic balance between carbon added and carbon removed.

\section{Kinetic Carbon-Isotope Effects}

A more quantitative interpretation of kinetic isotope effects involved with early diagenetic $\mathrm{CH}_{4}$ generation was given in connection with Leg 76, Hole 533 pore-fluid data (Claypool and Threlkeld, 1983). This treatment uses the open-system Rayleigh equations developed by Wigley et al. (1978) to model the concentration and $\delta^{13} \mathrm{C}$ change of dissolved $\mathrm{CO}_{2}$ reservoirs with depth (or time). The equations of Wigley et al. (1978) were extended for 


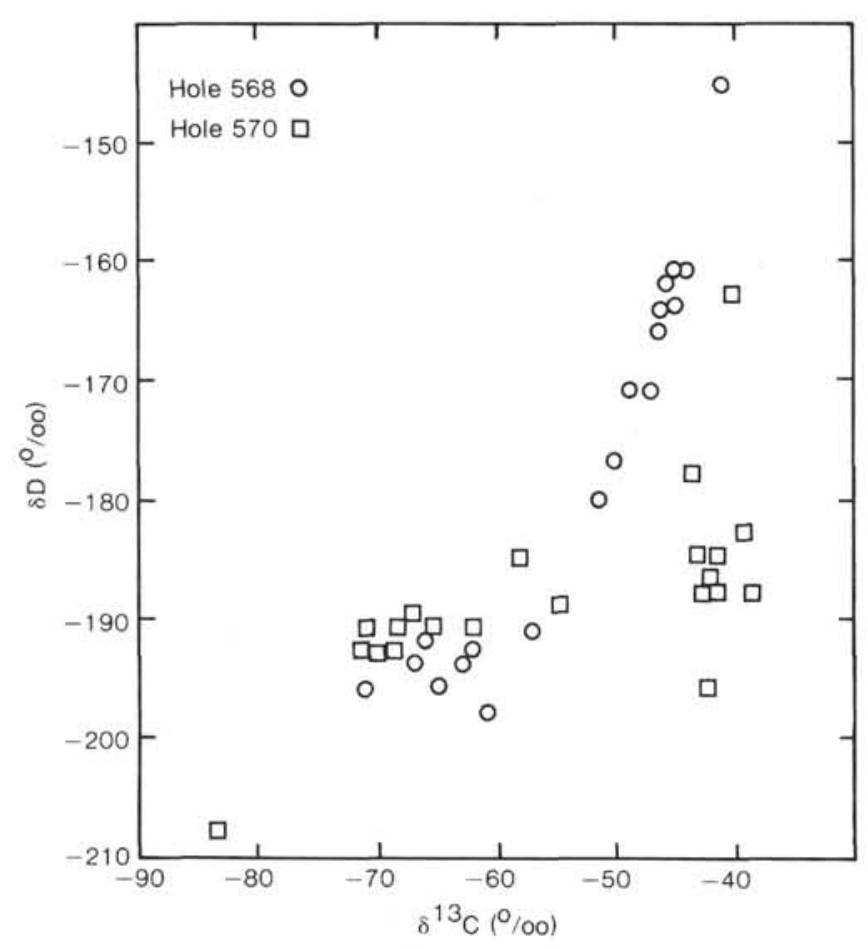

Figure 2. Crossplot of $\delta \mathrm{D}$ and $\delta^{13} \mathrm{C}$ in $\mathrm{CH}_{4}$ from DSDP Sites 568 and 570.

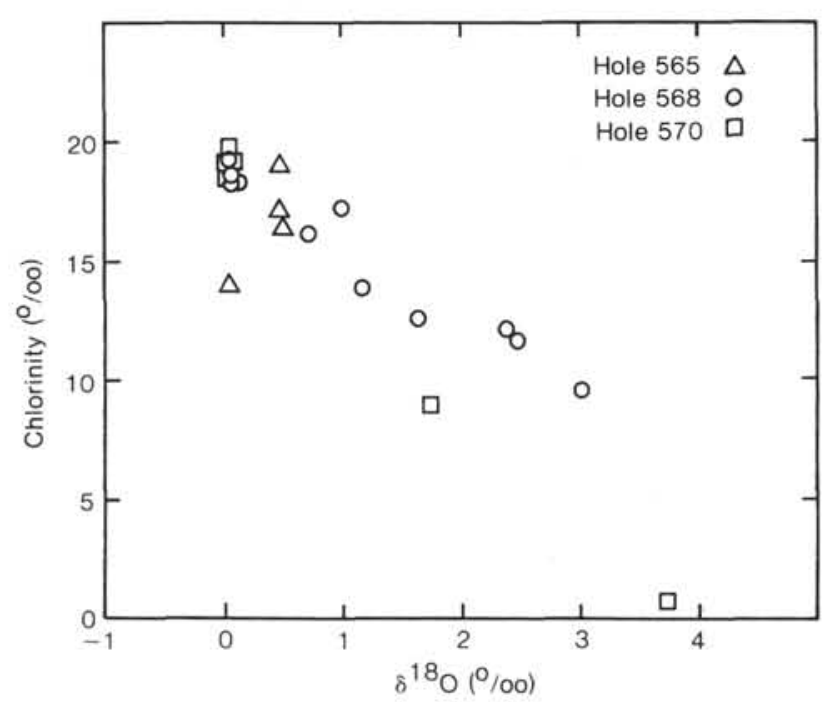

Figure 3. Crossplot of chlorinity and $\delta^{18} \mathrm{O}$ of pore water at DSDP Sites 565,568 , and 570 .

the Hole 533 data to give the $\delta^{13} \mathrm{C}$ and amount of cumulative $\mathrm{CH}_{4}$ production. The other parameters required are the $\mathrm{CO}_{2}$-input:total-output rate ratio and the $\mathrm{CH}_{4}$ output: $\mathrm{CO}_{3}$-output rate ratio. Trial-and-error combinations of these rate ratios can produce acceptable agreement between observed and calculated $\delta^{13} \mathrm{C}$ values and $\Sigma \mathrm{CO}_{2}$ concentrations. Results of such calculations for the Leg 84 data are summarized in Table 3.

The profiles of $\mathrm{\Sigma CO}_{2}$ concentration and $\delta^{13} \mathrm{C}$, and $\delta^{13} \mathrm{C}$ of $\mathrm{CH}_{4}$ for Holes 565,568 , and 570 were modeled over the depth intervals where $\mathrm{CH}_{4}$ production was the dominant diagenetic process and the $\mathrm{CO}_{2}$-depth relationship approximated a regular, monotonic function. A general pattern emerges from these input-output kinetic calculations. The initial stages of $\mathrm{CH}_{4}$ generation (typically from the onset to the first maxima in the $\mathrm{\Sigma CO}_{2}$ concentration-depth profile) can be modeled by a single-input $\left(\mathrm{CO}_{2}\right.$ with $\delta^{13} \mathrm{C}$ of $\left.-25 \%\right)$ :single-output $\left(\mathrm{CH}_{4}\right.$ with $70 \%$ kinetic ${ }^{12} \mathrm{C}$-enrichment) mechanism. Duplication of the $\Sigma \mathrm{CO}_{2}$ increase during the initial stages of $\mathrm{CH}_{4}$ generation requires that input:output rate ratios be greater than one. Later stages of $\mathrm{CH}_{4}$ generation, at depths where $\mathrm{CO}_{2}$ concentration is decreasing, usually cannot be adequately modeled by the one-input:one-output mechanism, because a given decrease in $\mathrm{\Sigma CO}_{2}$ is accompanied by a much larger degree of ${ }^{13} \mathrm{C}$-enrichment than is observed in DSDP pore waters. A one-input: two-output $\left(\mathrm{CH}_{4}\right.$ generation and $\mathrm{CO}_{3}$ precipitation) mechanism usually will duplicate the observed concentration and $\delta^{13} \mathrm{C}$ changes. The decreasing $\mathrm{\Sigma CO}_{2}$ concentration requires that the input:output rate ratio be less than one. The $\mathrm{CO}_{2}$ concentration decrease can be balanced with the appropriate $\delta^{13} \mathrm{C}$ increases for $\Sigma \mathrm{CO}_{2}$ and $\mathrm{CH}_{4}$ by adjusting the $\mathrm{CO}_{3}: \mathrm{CH}_{4}$ output rate ratio.

The purpose of these kinetic models is to show that several combinations of concentration and $\delta^{13} \mathrm{C}$ trends are possible in marine sediments. Variation in the relative rates of processes that are known to occur in anoxic marine sediments can produce the different $\mathrm{\Sigma CO}_{2}$ and $\delta^{13} \mathrm{C}$ gradients. The three main processes are $\mathrm{CO}_{2}$ generation via anaerobic respiration/oxidation of organic matter, $\mathrm{CO}_{2}$ reduction to $\mathrm{CH}_{4}$ (utilizing $\mathrm{H}_{2}$ /electrons generated by oxidation), and carbonate precipitation (usually dolomite, ankerite, or siderite) that is promoted by $\mathrm{pH}$ increase resulting from $\mathrm{CO}_{2}$-reduction. The observation of ${ }^{13} \mathrm{C}$-enrichment with increasing concentration of $\mathrm{\Sigma CO}_{2}$ is not necessarily incompatible with $\mathrm{CH}_{4}$ production by $\mathrm{CO}_{2}$ reduction, as has been stated by other investigators (Friedman and Murata, 1979; Carothers and Kharaka, 1980).

\section{Equilibrium Carbon-Isotope Effects}

If chemical species such as $\mathrm{CO}_{2}$ (gas), $\mathrm{HCO}_{3}{ }^{-}$, and $\mathrm{CO}_{3}^{2-}$ are exchanging atoms by reversible equilibrium reactions, then the carbon and oxygen of coexisting species should be in isotopic equilibrium. Equilibrium ${ }^{13} \mathrm{C} /$ ${ }^{12} \mathrm{C}$ fractionation between $\mathrm{CO}_{2}(\mathrm{~g})$ and $\mathrm{HCO}_{3}{ }^{-}$is given by the following equation (from the data of Mook et al., 1974):

$$
10^{3} \ln \alpha=9.55\left(10^{3} T^{-1}\right)-24.10
$$

where $T$ is temperature in $\mathrm{K}$, and

$$
\alpha=\frac{\left({ }^{13} \mathrm{C} /{ }^{12} \mathrm{C}\right)_{\mathrm{HCO}_{3}}{ }^{-}}{\left({ }^{13} \mathrm{C} /{ }^{12} \mathrm{C}\right)_{\mathrm{CO}_{2}}}
$$

is the fractionation factor between $\mathrm{HCO}_{3}{ }^{-}$and $\mathrm{CO}_{2}$.

The $\delta^{13} \mathrm{C}$ differences between $\mathrm{HCO}_{3}{ }^{-}$(as $\Sigma \mathrm{CO}_{2}$ ) and $\mathrm{CO}_{2}(\mathrm{~g})$ were estimated from the trends for Holes 568 
Table 3. Parameters of input-output carbon-isotope and mass-balance equations (Wigley et al., 1978) that satisfactorily reproduce concentration and $\delta^{13} \mathrm{C}$ of dissolved $\mathrm{CO}_{2}$ in interstitial water of Holes 568 and 570.

\begin{tabular}{|c|c|c|c|c|c|c|}
\hline \multirow[b]{2}{*}{ Hole } & \multirow{2}{*}{$\begin{array}{l}\text { Sub-bottom } \\
\text { depth } \\
\text { interval } \\
\text { (m) }\end{array}$} & \multicolumn{2}{|c|}{ Initial $\mathrm{HCO}_{3}{ }^{-}$} & \multirow{2}{*}{$\begin{array}{l}\text { No. of } \\
\text { inputs, } \\
\text { outputs }\end{array}$} & \multirow{2}{*}{$\begin{array}{l}\text { Input-to- } \\
\text { output } \\
\text { ratio }\end{array}$} & \multirow{2}{*}{$\begin{array}{l}\text { Carbonate- } \\
\text { to-methane } \\
\text { output } \\
\text { ratio }\end{array}$} \\
\hline & & $\left(\mathrm{mmol} \mathrm{kg}^{-1}\right)$ & $\begin{array}{c}{ }^{{ }^{13} \mathrm{C}} \\
\left(\%_{00}\right)\end{array}$ & & & \\
\hline \multirow[t]{5}{*}{568} & $10-25$ & 27 & -16 & 1,1 & 1.65 & 0 \\
\hline & $25-50$ & 75 & +15 & 1,1 & 1.62 & 0 \\
\hline & $50-100$ & 100 & +17 & 1,2 & 0.90 & 3 \\
\hline & $100-300$ & 70 & +20 & 1,2 & 0.90 & 12 \\
\hline & $300-400$ & 7 & +25 & 1,1 & 1.20 & 0 \\
\hline \multirow[t]{3}{*}{570} & $20-25$ & 40 & -25 & 1,1 & 0.84 & 0 \\
\hline & $55-87$ & 36 & +10 & 1,1 & 2.0 & 0 \\
\hline & $87-280$ & 51 & +10 & 1,2 & 0.80 & 1.5 \\
\hline
\end{tabular}

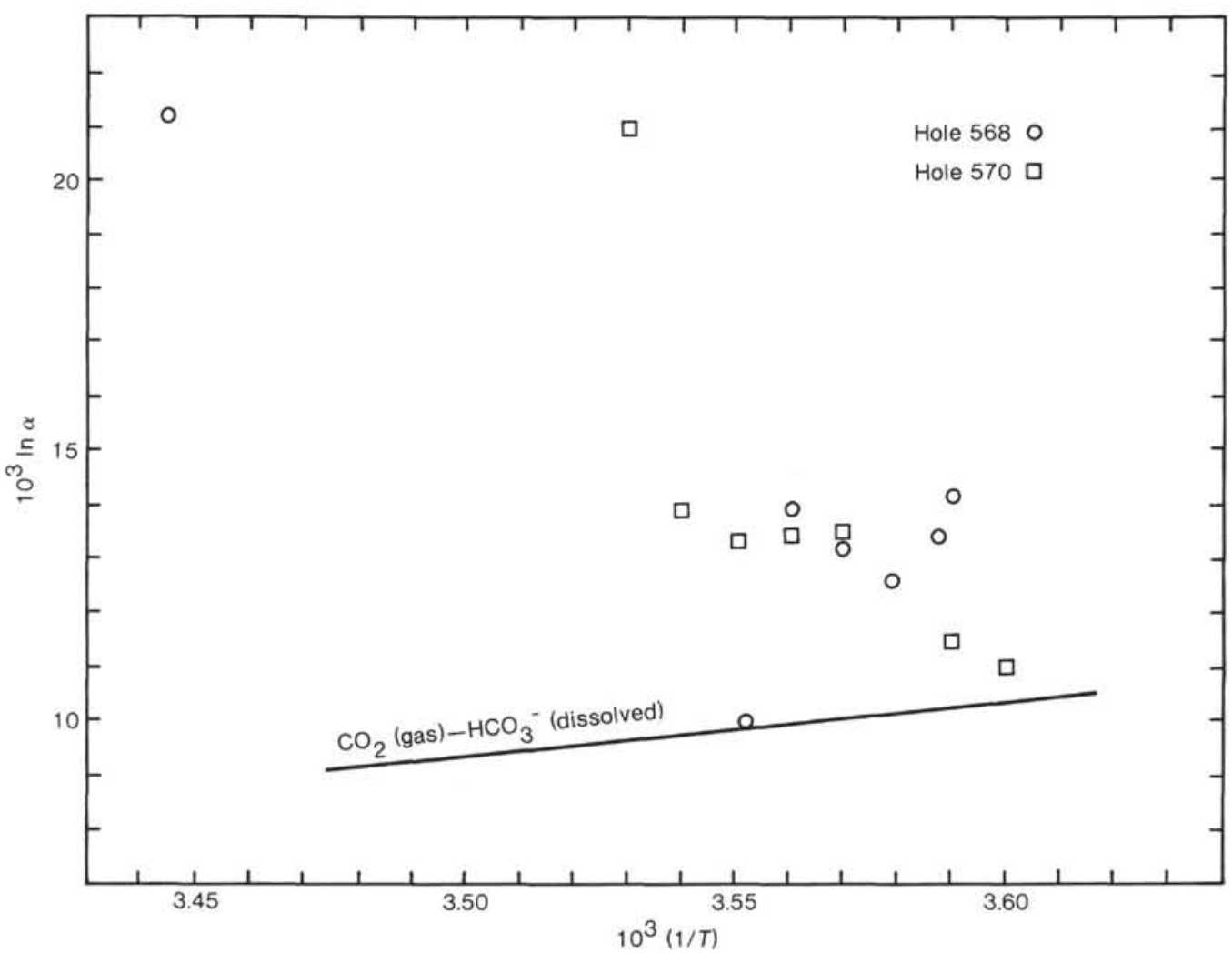

Figure 4. Observed $\delta^{13} \mathrm{C}$ differences between coexisting $\mathrm{CO}_{2}$ gas and dissolved $\mathrm{\Sigma CO}_{2}$ (calculated as $10^{3} \ln \alpha$; see text), plotted against estimated subsurface Kelvin temperature (as $10^{3} T^{-1}$ ). The points are calculated from the difference between the inferred trends with depth because gas and water sample pairs from the same depth are usually not available. The line shown for comparison is the theoretical $\mathrm{CO}_{2}-\mathrm{HCO}_{3}{ }^{-}$fractionation determined by Mook et al. (1974), as reported by Friedman and O'Neil (1977).

and 570 in Figure 1, and are plotted in Figure 4 as $\alpha_{e q}$ versus temperature. The temperature at any given depth was estimated from the bottom-water temperature and the thermal gradient (Kvenvolden and McDonald, this volume). The estimates of $\delta^{13} \mathrm{C}$ differences were made near the depths where $\delta^{13} \mathrm{C}$ of $\mathrm{CO}_{2}$ measurements were available from gas analyses. The agreement is not good between the equilibrium fractionation factors $\left(\alpha_{e q}\right)$ calculated from the Leg 84 observations and those given by controlled lab experiments (the line from the preceding equation). A majority of the points ( 9 of 15), however, fall in a band that is parallel to the equilibrium line but offset by $(3.5 \pm 1) \times 10^{3} \ln \alpha$. These points span the depth intervals from 50 to $100 \mathrm{~m}$ in Hole 568, and from 150 to $240 \mathrm{~m}$ in Hole 570 . In both holes, these are the depth intervals where the $\mathrm{\Sigma CO}_{2}$ and alkalinity concentrations show the greatest decrease, after reaching concentration maxima (Fig. 1). It can be assumed that the dissolved $\mathrm{CO}_{2}$-species are in isotopic equilibrium under in situ conditions in the Guatemala slope sediments. 
Therefore, the disagreement shown in Figure 4 must be due to various imperfections in the sampling and analytical procedures.

In contrast to isotopic equilibrium among species of the carbonate system, the assumption of carbon isotopic equilibrium between $\mathrm{CH}_{4}$ and $\mathrm{CO}_{2}$ in low-temperature sedimentary systems is not easily justified. Sackett and Chung (1979) observed no carbon-isotope exchange between $\mathrm{CH}_{4}$ and $\mathrm{CO}_{2}$ at $500^{\circ} \mathrm{C}$ for 10.5 days in the presence of mineral catalysts. Giggenbach (1982) reviews the relevant experimental data and suggests that any equilibration would be exceedingly slow ( $>10^{11}$ yrs.) at temperatures below $200^{\circ} \mathrm{C}$. Despite the lack of experimental support for low-temperature carbon isotopic equilibration of sedimentary $\mathrm{CH}_{4}$ and $\mathrm{CO}_{2}$, some geochemists still favor the interpretation of temperature-dependent equilibrium fractionation in the formation of these gases (Gould and Smith, 1979; Friedman and Murata, 1979; Carothers and Kharaka, 1980). The $\delta^{13} \mathrm{C}$ difference between $\mathrm{CH}_{4}$ and $\mathrm{CO}_{2}$ for Leg 84 pore fluids can be used to test the applicability of the equilibrium assumption. The calculations of Bottinga (1969, as plotted by Friedman and O'Niel, 1977) for the ${ }^{13} \mathrm{C} /{ }^{12} \mathrm{C}$ equilibrium fractionation between $\mathrm{CH}_{4}$ and $\mathrm{CO}_{2}$ gases for the tempera- ture range 0 to $100^{\circ} \mathrm{C}$ can be summarized (for the temperature range 0 to $20^{\circ} \mathrm{C}$ ) by the equation

$$
10^{3} \ln \alpha=27.05\left(10^{3} T^{-1}\right)-4.80
$$

where $T$ is temperature in $\mathrm{K}$, and

$$
\alpha=\frac{\left({ }^{13} \mathrm{C} /{ }^{12} \mathrm{C}\right)_{\mathrm{CO}_{2}}}{\left({ }^{13} \mathrm{C} /{ }^{12} \mathrm{C}\right)_{\mathrm{CH}_{4}}}
$$

Combining this equation with the equation given earlier for the $\mathrm{CO}_{2}(\mathrm{~g})-\mathrm{HCO}_{3}{ }^{-}$equilibrium fractionation, we can derive an equation for the $\mathrm{CH}_{4}-\mathrm{HCO}_{3}{ }^{-}$fractionation which is

$$
10^{3} \ln \alpha=36.6\left(10^{3} T^{-1}\right)-28.9
$$

The $\delta^{13} \mathrm{C}$ differences between the trends in Figure 1 for $\mathrm{CH}_{4}$ and $\Sigma \mathrm{CO}_{2}$ were plotted in Figure 5 as $\alpha_{e q}$ versus temperature, which was estimated in the manner already indicated. The lines shown are given by the equation for theoretical $\mathrm{CH}_{4}-\mathrm{HCO}_{3}{ }^{-}$equilibrium (upper line) and $\mathrm{CH}_{4}-\mathrm{CO}_{2}$ equilibrium (lower line). The $\alpha$ values calculated from the trends in Figure 1 deviate from the $\mathrm{CH}_{4}-$

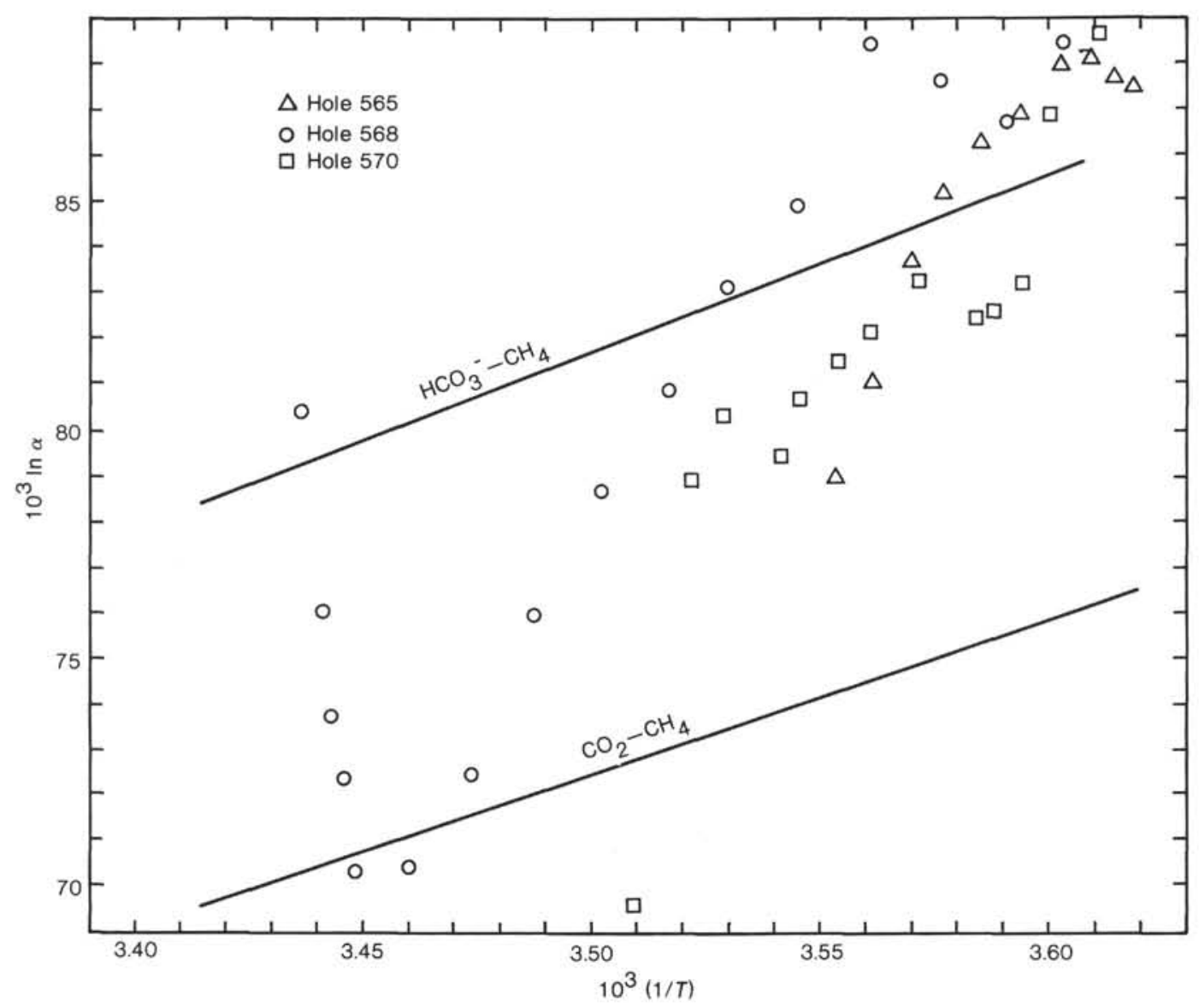

Figure 5. Observed $\delta^{13} \mathrm{C}$ differences between coexisting $\mathrm{CH}_{4}$ gas and dissolved $\mathrm{\Sigma CO}_{2}$ (calculated as $10^{3} \ln \alpha$ ), plotted against estimated subsurface Kelvin temperature $\left(\mathrm{as} 10^{3} \mathrm{~T}^{-1}\right.$ ). The points are regularly spaced depths along the inferred trends. The upper line is for theoretical $\mathrm{HCO}_{3}{ }^{-}-\mathrm{CH}_{4}$ fractionation, derived from the combined data of Bottinga (1969) and Mook et al. (1974). The lower line is $\mathrm{CO}_{2}-\mathrm{CH}_{4}$ fractionation as calculated by Bottinga (1969) and reported by Friedman and O'Neil (1977). 
$\mathrm{HCO}_{3}$ - equilibrium line by about +4 to $-20 \%$. Moreover, the detailed trends in the $\delta^{13} \mathrm{C}$ difference with increasing depth are significantly different from that predicted by temperature-dependent equilibrium. The calculated values are in only general agreement with what is predicted by equilibrium considerations. The kinetic approach to interpreting $\mathrm{CH}_{4}-\mathrm{CO}_{2} \delta^{13} \mathrm{C}$ differences is more useful because it incorporates consideration of amounts of reactants and products, and the relative rates of the biological processes.

\section{Gas-Hydrate Isotope Effects}

The correlation between increasing $\delta^{18} \mathrm{O}$ and decreasing chlorinity or salinity of pore water in sediments on the continental slope off Guatemala was first observed on Leg 67 (Harrison et al., 1982; Hesse and Harrison, 1981). The pore-water $\delta^{18} \mathrm{O}$ analyses reported in Table 1 and shown in Figure 3 for samples from Holes 568 and 570 confirm the Leg 67 observations. The water molecules that form the solid clathrate hydrate are known to exclude salts and concentrate ${ }^{18} \mathrm{O}$, relative to the coexisting liquid water (Davidson et al., 1983). The fractionation factor, $\alpha=\left({ }^{18} \mathrm{O} /{ }^{16} \mathrm{O}\right)_{\text {solid }} /\left({ }^{18} \mathrm{O} /{ }^{16} \mathrm{O}\right)_{\text {liquid, }}$, is believed to be about the same as that for the ice-water equilibrium (O'Neil, 1968), or about 1.003 . As shown in Table 1, pore-water samples with normal chlorinities have $\delta^{18} \mathrm{O}$ values in the range of 0.3 to $0.5 \%$, whereas water collected from decomposed gas hydrate from Core 27 of Hole 570 has $\delta^{18} \mathrm{O}$ of $3.72 \%$. If 0.5 and $3.7 \%$ are taken as the $\delta^{18} \mathrm{O}$ values of the liquid and solid $\mathrm{H}_{2} \mathrm{O}$, a value of $\alpha=1.0032$ is obtained.

The question of what happens to the salts and ${ }^{18} \mathrm{O}$ depleted $\mathrm{H}_{2} \mathrm{O}$ excluded during gas hydrate formation has not been resolved, but loss to overlying seawater or adjacent sediments seems to be required. An earlier interpretation (Hesse and Harrison, 1981) was that the gas hydrate probably is in contact with pore water of normal salinity and $\delta^{18} \mathrm{O}$. In this view, the observed "freshening" and ${ }^{18} \mathrm{O}$-enrichment is due to decomposition of gas hydrates during sampling and dilution of the pore water with water from the hydrate. The jagged depthprofiles for $\delta^{18} \mathrm{O}$ and chlorinity at Site 533 of Leg 76 support this interpretation (Jenden and Geiskes, 1983). However, results obtained with the in situ pore-water sampler in Hole 568 do not support this interpretation for the Guatemala slope sediments. The chlorinities of the in situ pore-water samples showed about the same $\mathrm{Cl}^{-}$-depletion as squeezed pore-water samples from similar depths. It should also be noted that pore water in Hole 570 does not show the regular changes in chlorinity and $\delta^{18} \mathrm{O}$ with depth. Only the water from decomposed gas hydrate at $249 \mathrm{~m}$ and the deepest samples (at 280 and $337 \mathrm{~m}$ ) shows significant departure from seawater/pore-water chlorinity and $\delta^{18} \mathrm{O}$.

Is the ${ }^{18} \mathrm{O}$-enrichment in $\mathrm{H}_{2} \mathrm{O}$ of gas hydrates accompanied by similar ${ }^{13} \mathrm{C}$ - and D-enrichment in the $\mathrm{CH}_{4}$ of gas hydrate? There is reason to expect that there would be some isotopic effect (Trofimuk et al., 1974), but the possible magnitude of such an effect is difficult to evaluate. $\mathrm{CH}_{4}$ hydrate is not easy to study experimentally, and the conditions required for its formation in the laboratory (vigorous stirring) make meaningful observation of possible isotopic effects difficult. No obvious isotopic effect has been observed during controlled decomposition of $\mathrm{CH}_{4}$ hydrate. Indirect evidence that gas hydrates are not the major cause of ${ }^{13} \mathrm{C}$-fractionation is provided by the fact that similar patterns of $\delta^{13} \mathrm{C}$ change with depth are observed in regions where gas hydrates are not stable, such as the Cariaco Trench (Claypool and Kaplan, 1974).

\section{SUMMARY AND CONCLUSIONS}

The pore-fluid samples from sediments in Holes 568 and 570 have extremely ${ }^{13} \mathrm{C}$-enriched early diagenetic $\mathrm{CH}_{4}$ and $\mathrm{CO}_{2}$ ( -41 and $+38 \%$, respectively). The sediments also have very high contents of organic matter (3-4\% organic carbon), and the best-developed marine gas-hydrate occurrences observed to date. The abundant organic matter should have supported prolonged and vigorous microbiological $\mathrm{CH}_{4}$ generation, with consequent extreme ${ }^{13} \mathrm{C}$-depletion in the $\Sigma \mathrm{CO}_{2}$ reservoir from which the $\mathrm{CH}_{4}$ was formed, and more extensive development of gas hydrates. Alternatively, methane generation could have resulted in the degree of ${ }^{12} \mathrm{C}$-enrichment that is typical for deep-sea sediments, and the development of gas hydrate may have superimposed additional fractionation and resulted in the observed extreme ${ }^{13} \mathrm{C}$-enrichment. Resolution of these alternative interpretations will have to await an improved understanding of the relevant diagenetic processes.

Isotopic compositions of other pore-fluid constituents $\left(\delta \mathrm{D}\right.$ of $\mathrm{CH}_{4}, \delta^{18} \mathrm{O}$ of $\left.\mathrm{H}_{2} \mathrm{O}\right)$ in continental-rise sediments of the Guatemala margin also exhibit systematic trends. The trends of isotopic composition with depth at the two sites differ significantly where gas hydrates either are massively developed at intermediate depths (Hole 570), or are disseminated and sufficiently developed to permit recovery only in the deepest part of the section penetrated (Hole 568). These different isotope-depth gradients may represent two different diagenetic styles or situations: one (Hole 570) in which the gradients are predominantly diffusion-controlled and gas hydrate development is concentrated at some preferred zone (e.g., beneath an unconformity), and another (Hole 568) in which there is progressive development of gas hydrate with increasing depth, and the gradients are predominantly those of steady-state diagenesis.

The pore-fluid data from DSDP Leg 84 provide abundant material for developing hypotheses regarding early diagenetic processes of the decomposition of organic matter in continental-margin sediments. Geochemical investigations to test these hypotheses should play a major role in planning for future deep-sea drilling.

\section{ACKNOWLEDGMENTS}

This work was funded in part by the Morgantown Energy Technology Center under USGS-USDOE interagency agreement no. DEA121-83MC20422, and by Gas Research Institute Contract No. 5081360-0533 to Global Geochemistry Corporation. Walter E. Dean and Zvi Sofer reviewed the manuscript, and D. R. Malone typed it.

\section{REFERENCES}

Bottinga, Y., 1969. Calculated fractionation factors for carbon and hydrogen isotope exchange in the system calcite- $\mathrm{CO}_{2}$-graphitemethane-hydrogen and water vapor. Geochim. Cosmochim. Acta, 33:49-64. 
Carothers, W. W., and Kharaka, Y. K., 1980. Stable carbon isotopes of $\mathrm{HCO}_{3}{ }^{-}$in oil-field waters-implications for the origin of $\mathrm{CO}_{2}$. Geochim. Cosmochim. Acta, 44:323-332.

Claypool, G. E., and Kaplan, I. R., 1974. The origin and distribution of methane in marine sediments. In Kaplan, I. R. (Ed.), Natural Gases in Marine Sediments: New York (Plenum), pp. 94-129.

Claypool, G. E., and Kvenvolden, K. A., 1983. Methane and other hydrocarbon gases in marine sediment. Ann. Rev. Earth Planet. Sci., 11:299-328.

Claypool, G. E., and Threlkeld, C. N., 1983. Anoxic diagenesis and methane generation in sediments of the Blake Outer Ridge, Deep Sea Drilling Project Site 533, Leg 76. In Sheridan, R. E., Gradstein, F. M., et al., Init. Repts. DSDP, 76: Washington (U.S. Govt. Printing Office), 391-402.

Claypool, G. E., Threlkeld, C. N., and Magoon, L. B., 1980. Biogenic and thermogenic origins of natural gas in Cook Inlet Basin, Alaska. Am. Assoc. Pet. Geol. Bull., 64:1131-1139.

Coleman, D. D., Lin, C., and Keogh, R. A., 1977. Isotopic identification of leakage gas from underground storage reservoirs-a progress report: Ill. State Geol. Surv. Ill. Petrol., 111:1-10.

Davidson, D. W., Leaist, D. G., and Hesse, R., 1983. Oxygen-18 enrichment in the water of a clathrate hydrate. Geochim. Cosmochim. Acta, 47:2293-2295.

Epstein, S., and Mayeda, T., 1953. Variation of oxygen-18 content of waters from natural sources. Geochim. Cosmochim. Acta, 4: 213-224.

Friedman, I., and Murata, K. J., 1979. Origin of dolomite in Miocene Monterey Shale and related formations in the Temblor Range, California. Geochim. Cosmochim. Acta, 43:1357-1365.

Friedman, I., and O'Neil, J. R., 1977. Compilation of stable isotope fractionation factors of geochemical interest. Data of Geochemistry (6th ed.), Geol. Surv. Prof. Pap. U.S., 440-KK:1-12.

Fuex, A. N., 1977. The use of stable carbon isotopes in hydrocarbon exploration. J. Geochem. Explor., 7:155-188.

Gealy, E. L., and Dubois, R., 1971. Shipboard geochemical analysis, Leg 7, Glomar Challenger. In Winterer, E. L., Riedel, W. R., et al., Init. Repts. DSDP, 7, Pt. 2: Washington (U.S. Govt. Printing Office), 863-870.

Giggenbach, W. F., 1982. Carbon-13 exchange between $\mathrm{CO}_{2}$ and $\mathrm{CH}_{4}$ under geothermal conditions. Geochim. Cosmochim. Acta, 46: $159-165$

Gould, K. W., and Smith, J. W., 1979. The genesis and isotopic composition of carbonates associated with some Permian Australian coals. Chem. Geol., 24:137-150.

Harrison, W. E., Hesse, R., and Geiskes, J. M., 1982. Relationship between sedimentary facies and interstitial water chemistry of slope, trench, and Cocos Plate sites from the Middle America Trench transect, active margin off Guatemala, DSDP Leg 67. In Aubouin, J., von Huene, R., et al., Init. Repts. DSDP, 67: Washington (U.S. Govt. Printing Office), 603-614.

Hesse, R., and Harrison, W. E., 1981. Gas hydrates (clathrates) causing pore-water freshening and oxygen isotope fractionation in deepwater sedimentary sections of terrigenous continental margins. Earth Planet. Sci. Lett., 55:453-462.

Jenden, P. D., and Geiskes, J. M., 1983. Chemical and isotopic composition of interstitial water from Deep Sea Drilling Project Sites 533 and 534. In Sheridan, R. E., Gradstein, F. M., et al., Init. Repts. DSDP, 76: Washington (U.S. Govt. Printing Office), 453-462.

Kvenvolden, K. A., and Barnard, L. A., 1983. Gas hydrates of the Blake Outer Ridge, Site 533, Deep Sea Drilling Project Leg 76. In Sheridan, R. E., Gradstein, F. M., et al., Init. Repts. DSDP, 76: Washington (U.S. Govt. Printing Office) 353-366.

Manheim, F. T., 1966. A hydraulic squeezer for obtaining interstitial water from consolidated and unconsolidated sediments. Geol. Surv. Prof. Pap. U.S., 550-C:256-261.

Mook, W. G., Bommerson, J. C., and Staverman, W. H., 1974. Carbon isotope fractionation between dissolved bicarbonate and gaseous carbon dioxide. Earth Planet. Sci. Lett., 22:169-176.

O'Neil, J. R., 1968. Hydrogen and oxygen isotope fractionation between ice and water. J. Phys. Chem., 72:3683-3684.

Presley, B. J., and Claypool, G. E., 1971. Techniques for analyzing interstitial water samples. Part II: Determination of total carbonate and carbon isotope ratios. In Winterer, E. L., Riedel, W. R., et al., Init. Repts. DSDP, 7, Pt. 2: Washington (U.S. Govt. Printing Office), 1756-1757.

Rosenfeld, W. D., and Silverman, S. R., 1959. Carbon isotope fractionation in bacterial production of methane. Science, 130:1658.

Sackett, W. M., and Chung, H. M., 1979. Experimental confirmation of the lack of carbon isotope exchange between methane and carbon oxides at high temperatures. Geochim. Cosmochim. Acta, 43: 273-276.

Schoell, M., 1980. The hydrogen and carbon isotopic composition of methane from natural gases of various origins. Geochim. Cosmochim. Acta, 44:649-661.

1983. Genetic characterization of natural gases. Am. Assoc. Pet. Geol. Bull., 67:2225-2238.

Trofimuk, A. A., Cherskiy, N. V. and Tsarev, V. P., 1974. Mechanisms for fractionation of isotopes of water and gas in crustal zones of hydrate formation. Dokl. Akad. Nauk SSSR, 215:1226-1229.

Wigley, T. M. L., Plummer, L. N., and Pearson, F. J., Jr., 1978. Mass transfer and carbon-isotope evolution in natural water systems. Geochim. Cosmochim. Acta, 42:1117-1140. 